\title{
Expression, Regulation, and Functions of the Galectin-16 Gene in Human Cells and Tissues
}

\author{
Jennifer D. Kaminker and Alexander V. Timoshenko *(D)
}

check for updates

Citation: Kaminker, J.D.;

Timoshenko, A.V. Expression,

Regulation, and Functions of the

Galectin-16 Gene in Human Cells and

Tissues. Biomolecules 2021, 11, 1909.

https://doi.org/10.3390/

biom 11121909

Academic Editor: Lu-Gang Yu

Received: 9 December 2021

Accepted: 16 December 2021

Published: 20 December 2021

Publisher's Note: MDPI stays neutral with regard to jurisdictional claims in published maps and institutional affiliations.

Copyright: (c) 2021 by the authors. Licensee MDPI, Basel, Switzerland. This article is an open access article distributed under the terms and conditions of the Creative Commons Attribution (CC BY) license (https:/ / creativecommons.org/licenses/by/ $4.0 /)$.

\begin{abstract}
Department of Biology, The University of Western Ontario, London, ON N6A 5B7, Canada; jkamink@uwo.ca * Correspondence: atimoshe@uwo.ca; Tel.: +1-519-661-2111 (ext. 88900)
\end{abstract}

\begin{abstract}
Galectins comprise a family of soluble $\beta$-galactoside-binding proteins, which regulate a variety of key biological processes including cell growth, differentiation, survival, and death. This paper aims to address the current knowledge on the unique properties, regulation, and expression of the galectin-16 gene (LGALS16) in human cells and tissues. To date, there are limited studies on this galectin, with most focusing on its tissue specificity to the placenta. Here, we report the expression and 8-Br-cAMP-induced upregulation of LGALS16 in two placental cell lines (BeWo and JEG-3) in the context of trophoblastic differentiation. In addition, we provide the results of a bioinformatics search for LGALS16 using datasets available at GEO, Human Protein Atlas, and prediction tools for relevant transcription factors and miRNAs. Our findings indicate that LGALS16 is detected by microarrays in diverse human cells/tissues and alters expression in association with cancer, diabetes, and brain diseases. Molecular mechanisms of the transcriptional and post-transcriptional regulation of LGALS16 are also discussed based on the available bioinformatics resources.
\end{abstract}

Keywords: galectin; LGALS16; placenta; brain tissues; cell differentiation; transcription factor; miRNA

\section{Introduction}

Galectins comprise a family of soluble $\beta$-galactoside binding proteins, which regulate key biological processes including cell growth, differentiation, apoptosis, and immune responses [1-4]. Sixteen galectin genes have been identified in animal kingdoms, 12 of which are expressed in humans. Galectins share a conserved carbohydrate recognition domain (CRD) and they are subcategorized into prototype, tandem-repeat, or chimeric type according to their number of CRDs and structural features. Prototype galectins contain one CRD and include galectins -1, -2, -5, -7, -10, -11, -13, -14, -15, and - 16 . Tandemrepeat galectins contain two homologous CRDs connected by a linker of $\sim 70$ amino acids and include galectins- $4,-6,-8,-9$, and -12 . The only chimera-type galectin is galectin- 3 , which contains one CRD linked to a non-lectin N-terminal proline/glycine-rich domain. Galectins form a network of proteins to perform glycan-dependent and glycan-independent functions both intra- and extracellularly [3-5]. Intracellularly, galectins have multiple binding partners and primarily function via glycan-independent mechanisms to regulate processes such as cell growth, apoptosis, and pre-mRNA splicing among others [4-6]. Extracellular galectins are secreted from cells through unconventional mechanisms [3,7] and can bind to glycoligands on the cell surface or glycoproteins in the extracellular matrix to promote cell adhesion and migration [8] or bind to specific cell surface receptors to facilitate their cross-linking and transmembrane signaling [3,8-10].

Galectin expression profiles vary significantly between different cells and tissues. Some galectins are commonly expressed with low tissue specificity, e.g., galectin- 1 and galectin-3, while others are highly-tissue specific [3]. LGALS16 was characterized in placental tissue by Than and co-authors [11] and together with two other galectins (LGALS13 and LGALS14) was found to be upregulated in differentiated trophoblast cells to confer immunotolerance at the maternal-fetal interface [12]. These three galectin genes are located in a cluster of four human protein-coding galectin genes on chromosome 19 and 
they are proposed to have evolutionarily emerged to sustain hemochorial placentation in anthropoids [11]. The correct expression of placenta-specific galectins is an important part of proper reprogramming of the transcriptional activity of the trophoblast [12]. This involves the differentiation and fusion of villous cytotrophoblasts into a multinucleated syncytium that is in direct contact with maternal blood and is responsible for facilitating gas, nutrient, and waste exchange between the mother and fetus, mediating hormonal regulation, and forming an immunological barrier during pregnancy [12]. Differentiated extravillous trophoblasts proliferate, invade, and remodel the maternal spiral arteries to provide blood flow and nutrients to the fetus [13]. Dysregulation of this placenta-specific gene cluster containing LGALS16 is associated with disorders such as preeclampsia, which can be highly fatal for both the mother and fetus [12-14].

Currently, experimental studies on LGALS16 are limited, although multiple microarray datasets and bioinformatics resources contain relevant information. Here, we use experimental and bioinformatics approaches for examining expression, regulation, and functions of LGALS16 to position this galectin within the complex galectin network in cells and to identify directions for future studies.

\section{Materials and Methods}

\subsection{Bioinformatics Data and Tools}

Microarray and RNA-sequencing data were extracted from the Gene Expression Omnibus (GEO) Profiles, which contained 287 datasets for LGALS16 (accessed on 2 November 2021), considering the following criteria: (1) inclusion of only controls and untreated cell/tissue samples, (2) inclusion of only cases with positive gene expression values for matched ACTB (a housekeeping gene), LGALS1 (a low tissue specific galectin), and LGALS16 genes, and (3) deletion of few datasets, which report enormous deviations (>100-folds) from average expression levels of ACTB and LGALS1 genes. In silico prediction of transcription factor binding sites in LGALS16 gene DNA sequence was performed with PROMO version 3.0.2 software, which utilized version 8.3 of TRANSFAC database $[15,16]$. The dissimilarity index for the transcription factor search was set at $0 \%$ to limit the number of non-specific matches. Ensembl Release 104 was used to extract the sequence of the $2 \mathrm{~kb}$ promoter region of the gene (accessed on 24 August 2021). Four different online platforms were used and compared to predict putative miRNA targets for LGALS16 including Diana Tools [17], miRabel [18], miRDB [19], and TargetScan [20]. The Human Protein Atlas (HPA) [21], GenBank [22], and Protein Data Bank (PDB) [23] were exploited for searching the relevant structures, sequences, and expression patterns of LGALS16 based on the gene symbol.

\subsection{Cell Cultures}

Placenta choriocarcinoma BeWo and JEG-3 cell lines (kindly provided by Dr. Renaud, Department of Anatomy and Cell Biology, Western University, London, ON, Canada) were cultured in Dulbecco's Modified Eagle Medium/Ham's F12 medium and RPMI-1640 medium, respectively, supplemented with $10 \%$ or $8 \%$ fetal bovine serum, $100 \mathrm{IU} / \mathrm{mL}$ penicillin, and $100 \mu \mathrm{g} / \mathrm{mL}$ streptomycin. Cell cultures were maintained in a $\mathrm{CO}_{2}$-incubator at $37^{\circ} \mathrm{C}$ and $5 \% \mathrm{CO}_{2}$. To induce trophoblastic differentiation, cells were grown in 6-well plates and treated with $250 \mu \mathrm{M}$ of 8-Br-cAMP (cat. \# B7880, Sigma-Aldrich, Oakville, ON, Canada) for $48 \mathrm{~h}$ (BeWo cells) or $36 \mathrm{~h}$ (JEG-3 cells). Over the time of these treatments, cell culture media was replaced one time for BeWo cells after $24 \mathrm{~h}$ of growth and two times (every $12 \mathrm{~h}$ ) for JEG-3 cells to avoid accumulation of acidic metabolites.

\subsection{Gene Expression Analysis}

The total RNA pools were isolated from cell monolayers using TRIzol ${ }^{\circledR}$ reagent (cat. \# 15596018, Ambion, Carlsbad, CA, USA) and $1 \mu \mathrm{g}$ was used for cDNA synthesis with the Advanced cDNA Synthesis Kit (cat. \# 801-100, Wisent, Montreal, QC, Canada). The conventional and quantitative polymerase chain reaction (PCR) analyses were used to assess the 
mRNA expression levels for following genes: ACTB, CGB3/5 (biomarkers of trophoblastic differentiation), and LGALS16. The oligonucleotide PCR primers for LGALS16 (forward 5'ATTTGCGAGTGCACTTAGGC-3' and reverse 5'-GACACACGTAGATGCGCAAG-3' , PCR amplicon length of $132 \mathrm{bp}$ ) targeting exon 3 (Figure 1) were designed using Primer-BLAST tool at NCBI [24]. Oligonucleotide primers for ACTB (forward 5'-TCAGCAAGCAGGAGTA TGACGAG-3' and reverse 5' $5^{\prime}$ ACATTGTGAACTTTGGGGGATG-3', PCR amplicon length of $265 \mathrm{bp}$ ) and CGB3/5 (forward 5'-CCTGGCCTTGTCTACCTCTT-3' ${ }^{\prime}$ and reverse $5^{\prime}$-GGCTT TATACCTCGGGGTTG-3', PCR amplicon length of $109 \mathrm{bp}$ ) were available elsewhere $[25,26]$. To run conventional PCR, reaction mixes $(10 \mu \mathrm{L} 2 X$ Taq FroggaMix (cat. \# FBTAQM, FroggaBio, Toronto, ON, Canada), $2 \mu \mathrm{L}$ forward and reverse primer mixture from $10 \mu \mathrm{M}$ stock, $7 \mu \mathrm{L}$ nuclease free water, and $1 \mu \mathrm{L}$ template cDNA) were loaded into a T100 Thermal Cycler (Bio-Rad Laboratories, Mississauga, ON, Canada) and amplified using the following PCR regime: 26 cycles of $94{ }^{\circ} \mathrm{C}$ for $3 \mathrm{~min}, 94^{\circ} \mathrm{C}$ for $30 \mathrm{~s}, 56^{\circ} \mathrm{C}$ seconds, $72{ }^{\circ} \mathrm{C}$ for $60 \mathrm{~s}, 72{ }^{\circ} \mathrm{C}$ for $10 \mathrm{~min}$, and held at $4{ }^{\circ} \mathrm{C}$. The PCR products were separated on a $2 \%$ agarose gel as described earlier [27] and the gel was imaged using the Molecular Imager ${ }^{\circledR}$ Gel Doc $^{\mathrm{TM}}$ $\mathrm{XR}+($ Bio-Rad) to confirm the expected size of PCR amplicons. The quantitative PCR was performed in the CFX Connect ${ }^{\mathrm{TM}}$ Thermocycler and quantified as described previously [28] using the SsoAdvanced Universal SYBR ${ }^{\circledR}$ Supermix kit (cat. \# 1725274, Bio-Rad Laboratories, Mississauga, ON, Canada). To assess the expression of 84 genes encoding human transcription factors, the $\mathrm{RT}^{2}$ Profiler ${ }^{\mathrm{TM}}$ PCR Array Kit (cat. \# PAHS-075ZD-2, Qiagen, Toronto, ON, Canada) was used following the protocols provided by the manufacturer.

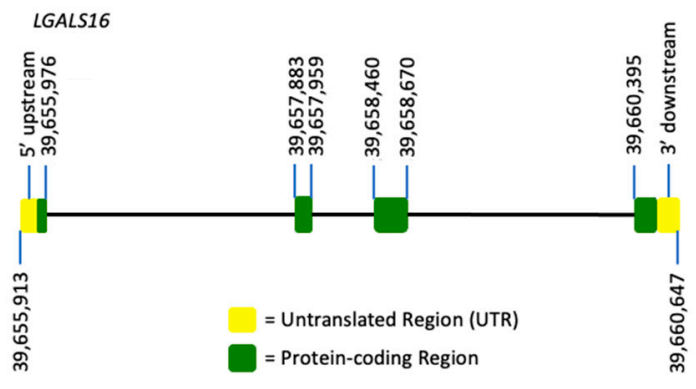

(a)

\begin{abstract}
1 actcagaagactggacacaattccgaaggtcgcccagaaggagaggacaATGTCATTTCT 61 AACTGTGCCATACAAACTGCCTGTGTCTTTGTCTGTTGGTTCCTGCGTGATAATCAAAGG 121 GACACTGATCGACTCTTCTATCAACGAACCACAGCTGCAGGTGGATTTCTACACTGAGAT 181 GAATGAGGACTCAGAAATTGCCTTCCATTTGCGAGTGCACTTAGGCCGTCGTGTGGTCAT 241 GAACAGTCGTGAGTTTGGGATATGGATGTTGGAGGAGAATTTACACTATGTGCCCTTTGA 301 GGATGGCAAACCATTTGACTTGCGCATCTACGTGTGTCACAATGAGTATGAGGTAAAGGT 361 AAATGGTGAATACATTTATGCCTTTGTCCATCGAATCCCGCCATCATATGTGAAGATGAT 421 TCAAGTGTGGAGAGATGTCTCCCTGGACTCAGTGCTTGTCAACAATGGACGGAGATGAtc 481 acactcctcattgttgaggaa accctctttctacctgaccatgggattcctagagcctgc 541 taacagataatccctcctca a cccttcccctacacttggtcattaaacagcaccaa 601 ccgta
\end{abstract}

(b)

Figure 1. LGALS16 gene structure and the mRNA sequence. (a) LGALS16 (4735 bp) is located on chromosomal band $19 \mathrm{q} 13.2$ and contains 4 exons (ENSG00000249861). (b) NCBI reference sequence of LGASL16 mRNA (NM_001190441.3). Each exon is highlighted with red, orange, blue, and black representing exons 1, 2, 3, and 4, respectively. The protein coding sequence (CDS) is indicated in capitals while UTRs in small characters. The oligonucleotide sequences for PCR amplification are boxed.

\subsection{Statistical Analysis}

Statistical analysis was performed using GraphPad Prism 9 for Windows, version 9.1.2 (GraphPad Software, San Diego, CA, USA) and the data were presented as mean \pm SD. One-way analysis of variance (ANOVA) was used to determine statistical significance across treatments followed by Tukey's honestly significant difference test to detect which means were statistically significant at a value of $p<0.05$.

\section{Results and Discussion}

\subsection{Molecular Characteristics of Galectin-16 Gene and Recombinant Protein}

The LGALS16 gene structure and molecular details were described by Than and coauthors [11]. LGALS16 (4735 bp) is located on chromosomal band 19q13.2, spans from bases 39,655,913 to 39,660,647, and contains 4 exons (Figure 1a,b). LGALS16 is found only in primates and is part of the chromosome 19 gene cluster containing four proteincoding genes (LGALS10, LGALS13, LGALS14, LGALS16) [11,12,14,29]. The diversification and evolutionary origin of this cluster, including $L G A L S 16$, is thought to be related to placenta development and mediated by transposable long interspersed nuclear elements 
(LINEs), which are commonly found at the boundaries of large inversions and gene duplication units $[11,30,31]$. The relevant rearrangements and subsequent gains and losses of duplicated genes and pseudogenes are proposed to have enabled anthropoids to sustain highly invasive placentation and placental phenotypes, such as longer gestation for larger offspring and an increased body to brain size ratio [11].

To the best of our knowledge, no studies are available on native galectin-16 at the protein level whereas recombinant protein has been produced and tested. The crystal structure of recombinant galectin-16 and its mutants was solved by $\mathrm{Si}$ and co-authors [32]. Recombinant galectin- 16 is a monomeric protein, which is composed of 142 amino acids and has a typical galectin structure of the CRD $\beta$-sandwich with two sheets formed by six $\beta$-strands on the concave side (S1-S6) and five $\beta$-strands on the convex side (F1-F5) (Figure 2). This group also showed that galectin-16 lacks lactose-binding ability unless arginine (Arg55) is replaced with asparagine in S4 $\beta$-strand. In comparison, an earlier report showed that recombinant galectin-16 and two other human galectins (galectin-13 and galectin-14) can bind lactose-agarose beads and are efficiently and competitively eluted by lactose [11]. More insights into this discrepancy are required considering multiple interfering factors, mutations/replacements of amino acids within the CRD, and different study designs. Regardless, both glycan-dependent and glycan-independent interactions might be essential for galectin-16 similar to other galectins [3].

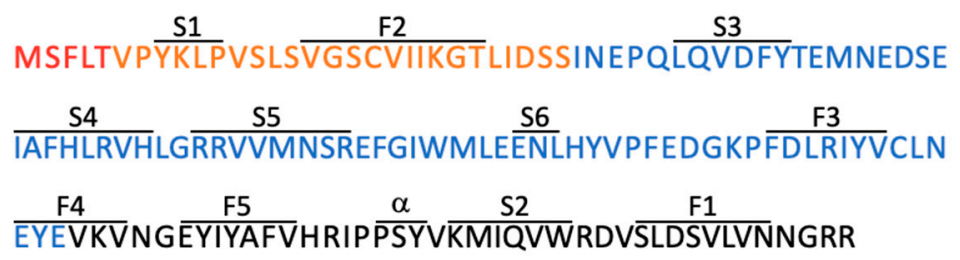

(a)

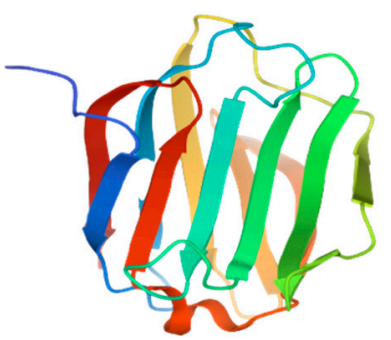

(b)

Figure 2. Protein sequence and structure of recombinant galectin-16. (a) The 142 amino acid sequence is $16.6 \mathrm{kDa}$ for the galectin-16 protein. Each color corresponds to the exon from which the amino acids were encoded with red, orange, blue, and black representing exons 1, 2, 3, and 4, respectively. The anti-parallel $\beta$-sheets of F-face (F1-F5) and S-face (S1-S6) strands as well as a short $\alpha$-helix are showed. (b) The crystal structure was extracted from Protein Data Bank (available online: rcsb.org, accessed on 6 September 2021), PDB ID: 6LJP.

\subsection{Expression Patterns and Functions of LGALS16 in Cells and Tissues}

Experimental studies focusing on LGALS16 are limited and an essential source of relevant information about this gene is Gene Expression Omnibus (GEO), a data repository for microarray and RNA-sequencing data [33]. Overall, 287 datasets are available on GEO (November 2021 search) reporting LGALS16 expression in 52 types of tissues and various cell lines based on the following platforms: Affymetrix Human Genome $(n=27)$, Affymetrix Human Gene $(n=151)$, Agilent $(n=31)$, Human Unigene $(n=1)$, Illumina Human $(n=82)$, MCI Human $(n=1)$, NuGO $(n=1)$, and Sentrix Human $(n=15)$. Quantification of differences in LGALS16 expression between different platforms is challenging. However, evaluation of gene expression values within the same GEO datasets demonstrates that LGALS16 can be classified as a gene with relatively low expression in comparison with LGALS1 (a widely expressed galectin with a low tissue specificity) and ACTB (a common housekeeping gene) (Table 1). Indeed, regardless of the platform, average GEO percentile rank of expression for LGALS16 measured with different arrays ranged $4-32 \%$ on a scale of $1-100 \%$ while the range was $63-100 \%$ for $L G A L S 1$ and $94-100 \%$ for ACTB. Available GEO profiles do not contain relevant datasets with LGALS16 for placenta for comparison, however, the Human Protein Atlas (HPA) reports tissue-specific overexpression of LGALS16 in placenta followed by brain tissues and retina (Figure 3a). The biological meaning and reasons of overexpression of LGALS16 in these diverse tissues is unknown and requires 
further investigations in the context of developmental biology. For instance, the complex mechanisms of the placenta-brain axis of cell development [34] could be addressed in terms of the unique association of LGALS16 with these tissues.

Table 1. Comparative expression of LGALS16 in human tissues and cells from the Gene Expression Omnibus database.

\begin{tabular}{|c|c|c|c|c|c|}
\hline Names of Cells or Tissues & GEO Accession Number & АСТВ & LGALS1 & LGALS16 & Sample Size \\
\hline Acetabular labrum cells & GDS5427 $^{\mathrm{a}}$ & $12.682 \pm 0.150$ & $12.057 \pm 0.107$ & $2.949 \pm 0.0093$ & 3 \\
\hline $\begin{array}{l}\text { Acute lymphoblastic leukemia cell } \\
\text { line RS4;11 }\end{array}$ & GDS4043 b & $13.861 \pm 0.017$ & $11.487 \pm 0.033$ & $0.4023 \pm 0.607$ & 2 \\
\hline $\begin{array}{l}\text { Acute myeloblastic leukemia cell } \\
\text { line Kasumi-1 }\end{array}$ & GDS5600 a & $11.965 \pm 0.025$ & $6.455 \pm 0.299$ & $2.918 \pm 0.036$ & 3 \\
\hline Acute promyelocytic leukemia cell line NB4 & GDS4180 a & $13.130 \pm 0.035$ & $10.823 \pm 0.031$ & $3.650 \pm 0.108$ & 3 \\
\hline Adipocyte progenitor cells (subcutaneous) & GDS5171 ${ }^{\mathrm{a}}$ & $13.523 \pm 0.038$ & $13.397 \pm 0.112$ & $4.597 \pm 0.251$ & 6 \\
\hline Adipocyte progenitors from deep neck & GDS5171 $^{\text {a }}$ & $13.469 \pm 0.057$ & $13.208 \pm 0.177$ & $4.505 \pm 0.094$ & 6 \\
\hline $\begin{array}{l}\text { Bone marrow CD34+ cells (chronic } \\
\text { myeloid leukemia) }\end{array}$ & GDS4756 a & 13.524 & 11.137 & 3.050 & 1 \\
\hline Bone marrow plasma cells & GDS4968 ${ }^{\text {a }}$ & $11.990 \pm 0.226$ & $8.714 \pm 0.515$ & $3.052 \pm 0.257$ & 5 \\
\hline Brain frontal cortex & GDS4758 a & $13.402 \pm 0.125$ & $96.333 \pm 0.840$ & $4.632 \pm 0.249$ & 18 \\
\hline Brain hippocampus & GDS4758 ${ }^{\text {a }}$ & $13.477 \pm 0.130$ & $11.133 \pm 0.375$ & $4.659 \pm 0.300$ & 10 \\
\hline Brain hippocampus & GDS4879 a & $12.113 \pm 0.409$ & $9.076 \pm 0.232$ & $3.177 \pm 0.177$ & 19 \\
\hline Brain temporal cortex & GDS4758 ${ }^{\text {a }}$ & $13.560 \pm 0.131$ & $11.189 \pm 0.280$ & $4.749 \pm 0.193$ & 19 \\
\hline Breast cancer cell line MCF-7 & GDS2759 b & $15.884 \pm 0.030$ & $13.752 \pm 0.153$ & $6.053 \pm 0.237$ & 2 \\
\hline Breast cancer cell line MCF-7 & GDS4972 a & $13.029 \pm 0.038$ & $12.439 \pm 0.083$ & $3.892 \pm 0.066$ & 3 \\
\hline Breast cancer cell line MCF-7 & GDS4090 a & $13.087 \pm 0.019$ & $9.566 \pm 0.100$ & $2.827 \pm 0.405$ & 3 \\
\hline Breast cancer cell line MDA-MB-231 & GDS4800 a & $13.875 \pm 0.007$ & $13.565 \pm 0.042$ & $5.189 \pm 0.085$ & 3 \\
\hline Bronchial smooth muscle primary cells & GDS4803 a & $11.629 \pm 0.175$ & $11.533 \pm 0.041$ & $3.181 \pm 0.095$ & 3 \\
\hline $\begin{array}{l}\text { Bronchopulmonary neuroendocrine cell } \\
\text { line NCI-H727 }\end{array}$ & GDS4330 a & 11.978 & 5.715 & 3.808 & 1 \\
\hline Burkitt lymphoma cell line Namalwa & GDS4978 a & $13.468 \pm 0.187$ & $8.005 \pm 0.073$ & $3.916 \pm 0.297$ & 3 \\
\hline Burkitt lymphoma cell line Raji & GDS4978 a & $13.367 \pm 0.093$ & $8.052 \pm 0.141$ & $3.962 \pm 0.019$ & 3 \\
\hline Colorectal adenocarcinoma cell line SW620 & GDS5416 ${ }^{\mathrm{e}}$ & $16.400 \pm 0.362$ & $17.280 \pm 0.043$ & $2.766 \pm 0.554$ & 2 \\
\hline Embryonic kidney cell line HEK-293 & GDS4233 a & $10.330 \pm 0.050$ & $7.109 \pm 0.098$ & $3.757 \pm 0.328$ & 4 \\
\hline Endothelial progenitor cells & GDS3656 ${ }^{c}$ & $15.397 \pm 0.174$ & $13.845 \pm 0.457$ & $8.018 \pm 0.103$ & 11 \\
\hline Esophagus biopsies & GDS4350 a & $12.617 \pm 0.230$ & $8.062 \pm 0.507$ & $3.255 \pm 0.208$ & 8 \\
\hline $\begin{array}{l}\text { Gastrointestinal neuroendocrine cell } \\
\text { line KRJ-1 }\end{array}$ & GDS4330 a & 12.135 & 9.592 & 2.859 & 1 \\
\hline Germinal center B cells & GDS4977 a & $9.793 \pm 0.373$ & $8.438 \pm 0.225$ & $6.723 \pm 0.538$ & 5 \\
\hline Gingival fibroblasts & GDS5811 ${ }^{\mathrm{a}}$ & $13.628 \pm 0.101$ & $13.770 \pm 0.174$ & $3.674 \pm 0.140$ & 2 \\
\hline Heart (left ventricle) & GDS4772 a & $11.293 \pm 0.361$ & $10.672 \pm 0.377$ & $2.941 \pm 0.030$ & 5 \\
\hline Heart (left ventricle) & GDS4314 ${ }^{\text {a }}$ & $12.142 \pm 0.365$ & $11.052 \pm 0.223$ & $3.344 \pm 0.154$ & 5 \\
\hline Heart (right ventricular) & GDS5610 a & $11.930 \pm 0.255$ & $10.934 \pm 0.044$ & $3.637 \pm 0.181$ & 2 \\
\hline Hepatocellular carcinoma cell line HepG2 & GDS5340 a & $13.259 \pm 0.039$ & $11.256 \pm 0.054$ & $4.281 \pm 0.327$ & 3 \\
\hline Microglia cell line HMO6 & GDS4151 a & 13.545 & 12.231 & 2.979 & 1 \\
\hline Keratinocytes & GDS4426 ${ }^{a}$ & $12.679 \pm 0.056$ & $11.147 \pm 0.236$ & $3.804 \pm 0.138$ & 6 \\
\hline Lung carcinoma cell line A549 & GDS4997 a & $10.970 \pm 0.044$ & $12.187 \pm 0.049$ & $2.418 \pm 0.072$ & 3 \\
\hline Lung carcinoma cell line $\mathrm{H} 460$ & GDS5247 $^{\text {a }}$ & $12.504 \pm 0.043$ & $11.111 \pm 0.063$ & $3.439 \pm 0.117$ & 3 \\
\hline $\begin{array}{l}\text { Lung microvascular endothelial cell } \\
\text { line CC-2527 }\end{array}$ & GDS2987 b & $32,061 \pm 7366$ & $15,158 \pm 2227$ & $8.100 \pm 9.051$ & 2 \\
\hline Lymphoblastoid cell line TK6 & GDS4915 a & $13.365 \pm 0.061$ & $11.161 \pm 0.323$ & $4.005 \pm 0.327$ & 2 \\
\hline Lymphoblastoid cell line TK6 & GDS4916 ${ }^{a}$ & $13.940 \pm 0.058$ & $12.023 \pm 0.130$ & $4.061 \pm 0.357$ & 2 \\
\hline Medulloblastoma tumor tissue & GDS4469 a & $13.099 \pm 0.302$ & $9.490 \pm 0.801$ & $4.005 \pm 0.839$ & 15 \\
\hline Melanoma cell line A-375 & GDS5085 a & $13.888 \pm 0.011$ & $13.474 \pm 0.101$ & $4.618 \pm 0.045$ & 3 \\
\hline Melanoma cell line FEMX-I & GDS3489 d & $16.04 \pm 0.354$ & $16.04 \pm 0.354$ & $0.550 \pm 1.061$ & 2 \\
\hline Melanoma cell line Hs294T & GDS5670 a & $11.353 \pm 0.245$ & $10.349 \pm 0.097$ & $2.149 \pm 0.585$ & 2 \\
\hline Microglia cell line HMO6 & GDS4151 a & 13.545 & 12.231 & 2.979 & 1 \\
\hline Myotubes from musculus obliquus internus & GDS5378 a & $13.224 \pm 0.099$ & $12.925 \pm 0.114$ & $2.840 \pm 0.057$ & 4 \\
\hline Pancreatic neuroendocrine cell line QGP-1 & GDS4330 a & 12.057 & 5.749 & 3.031 & 1 \\
\hline $\begin{array}{l}\text { Peripheral blood CD34+ cells (chronic } \\
\text { myeloid leukemia) }\end{array}$ & GDS4756 $^{\text {a }}$ & $13.414 \pm 0.049$ & $11.144 \pm 0.578$ & $2.974 \pm 0.140$ & 2 \\
\hline Peripheral blood CD4+ T cells & GDS5544 ${ }^{\text {a }}$ & $13.598 \pm 0.053$ & $9.707 \pm 0.247$ & $4.584 \pm 0.126$ & 4 \\
\hline Peripheral blood cells & GDS4240 a & $11.825 \pm 0.084$ & $7.307 \pm 0.154$ & $1.506 \pm 0.112$ & 7 \\
\hline Renal adenocarcinoma cell line 786-O & GDS5810 ${ }^{a}$ & $12.902 \pm 0.030$ & $12.809 \pm 0.015$ & $5.753 \pm 0.031$ & 2 \\
\hline Retinal pigment epithelia primary cells & GDS4224 ${ }^{\text {a }}$ & $13.407 \pm 0.110$ & $11.842 \pm 0.449$ & $3.468 \pm 0.367$ & 4 \\
\hline $\begin{array}{l}\text { Retinal pigmented epithelium cell } \\
\text { line ARPE-19 }\end{array}$ & GDS4224 a & 13.288 & 11.946 & 3.646 & 1 \\
\hline $\begin{array}{l}\text { Skeletal muscle (vastus lateralis) } \\
\text { primary cells }\end{array}$ & GDS4920 a & $13.649 \pm 0.084$ & $13.385 \pm 0.114$ & $4.609 \pm 0.136$ & 12 \\
\hline
\end{tabular}


Table 1. Cont.

\begin{tabular}{|c|c|c|c|c|c|}
\hline Names of Cells or Tissues & GEO Accession Number & АСТВ & LGALS1 & LGALS16 & Sample Size \\
\hline Skeletal muscle tissue & GDS4841 ${ }^{\mathrm{a}}$ & $9.400 \pm 0.190$ & $11.486 \pm 0.247$ & $2.786 \pm 0.355$ & 5 \\
\hline Skin cancer cell line RT3Sb & GDS5381 ${ }^{a}$ & $13.409 \pm 0.062$ & $8.775 \pm 0.114$ & $3.539 \pm 0.252$ & 4 \\
\hline Skin epidermis & GDS3806 ${ }^{c}$ & $15.139 \pm 0.141$ & $9.534 \pm 0.370$ & $7.909 \pm 0.469$ & 7 \\
\hline Visceral adipose tissue (omentum) & GDS4857 ${ }^{a}$ & $11.875 \pm 0.352$ & $11.488 \pm 0.416$ & $4.666 \pm 0.754$ & 8 \\
\hline
\end{tabular}

Notes: The means \pm SD of available gene expression values are shown. The GEO datasets originated from different platforms: ${ }^{2}$ Affymetrix Human Gene 1.0 ST Array, b Sentrix Human-6 Expression BeadChip, c Sentrix HumanRef-8 Expression BeadChip, d MCI Human

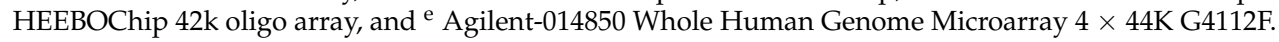

\section{Tissues}

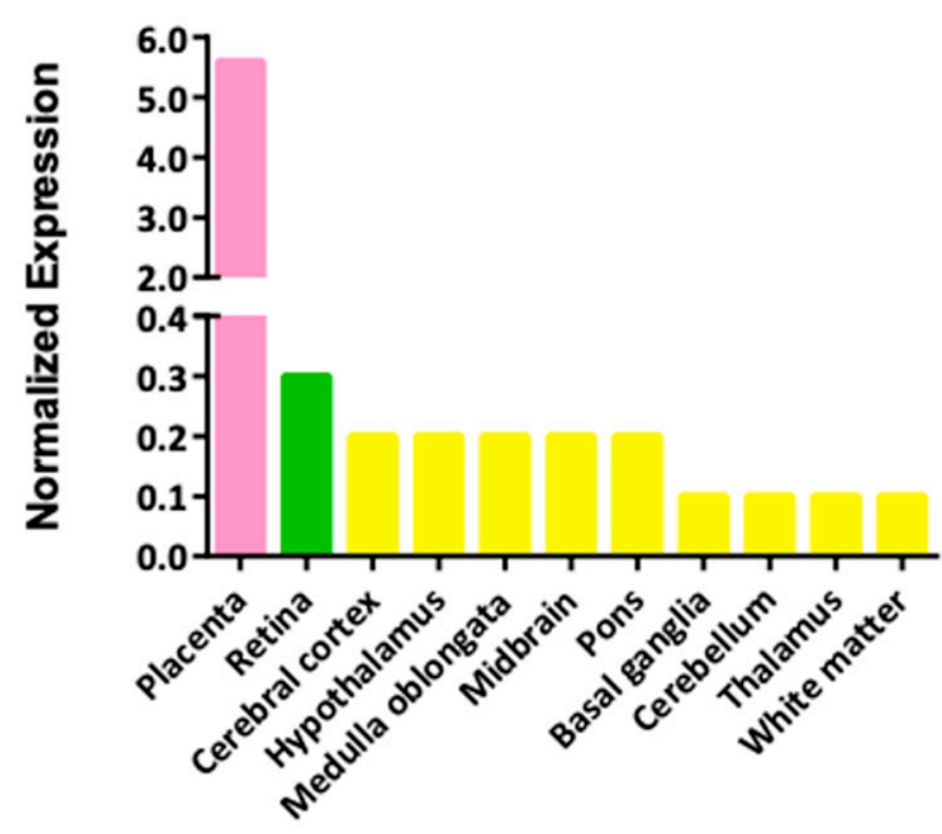

(a)

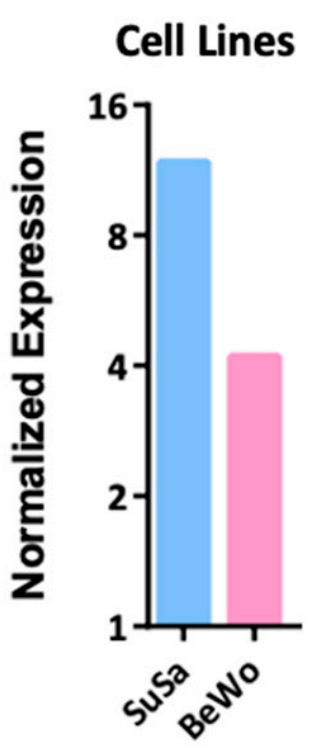

(b)

Figure 3. The normalized expression of LGALS16 mRNA in human tissues and cells from HPA datasets. (a) LGALS16-positive cases out of 55 tissue types; (b) LGALS16-positive cases out of 69 cell lines. The data were retrieved on 28 November 2021.

In comparison with tissues, HPA reports the expression of LGALS16 mRNA only in two human cell lines including placental choriocarcinoma cell line BeWo and testicular teratoma cell line SuSa, which probably can be used as appropriate systems to explore the biological role of LGALS16 gene (Figure 3b). Human syncytiotrophoblasts, which are terminally differentiated placental cells, can also serve as a strong positive control for LGALS16 overexpression [10-12].

To develop experimental models for studying LGALS16 functions and regulation, we examined the gene expression in BeWo cells and an additional placental cell line JEG-3 in the context of trophoblastic differentiation. The expression of LGALS16 mRNA was significantly increased in both cell lines after 36 h (JEG-3 cells) and 48 h (BeWo cells) treatment with a potent cell-permeable and metabolically stable activator of cAMPdependent protein kinase 8-Br-cAMP $(250 \mu \mathrm{M})$, which coincided with upregulation of CGB3/5, genes encoding chorionic gonadotropin subunits 3 and 5 (Figure 4). As chorionic gonadotropin is one of the biomarkers of placenta and trophoblastic differentiation, our results suggest classifying LGALS16 to the same category of biological molecules. Other studies also reported significant upregulation of LGALS16 in association with processes of cellular differentiation, even if the basal levels were relatively low. Thus, treatment of BeWo cells with forskolin, an inducer of cyclic adenosine $3^{\prime}, 5^{\prime}$-monophosphate (cAMP), 
stimulated trophoblastic differentiation and simultaneous LGALS16 overexpression [12]. An interesting example of LGALS16 upregulation was reported in a model of intestinal differentiation of Caco- 2 cells induced by a combined treatment with dexamethasone and p44/42 MAPK inhibitor PD98059 [35]. Therefore, LGALS16 may deserve further attention as a factor associated with processes of cellular differentiation and tissue development.
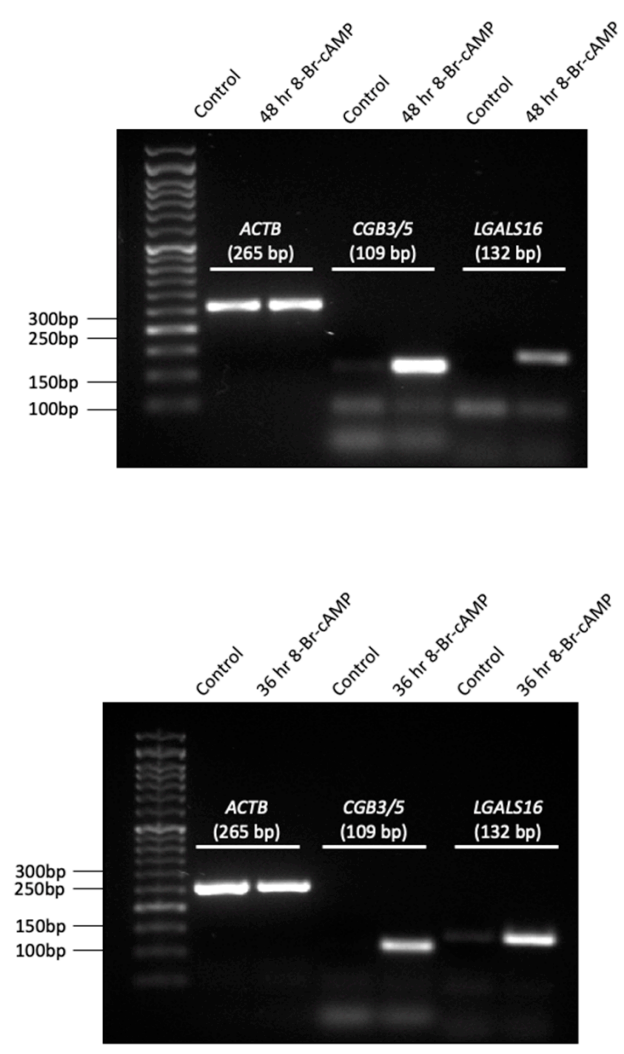

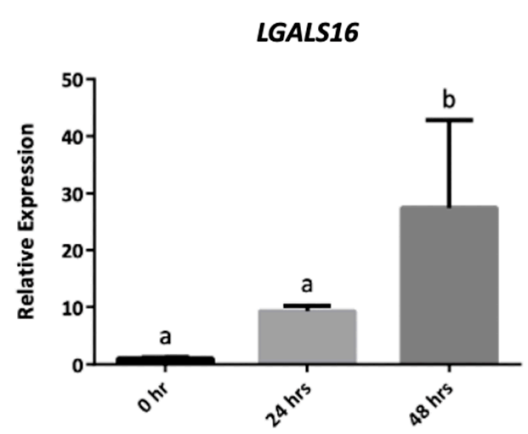

(a)
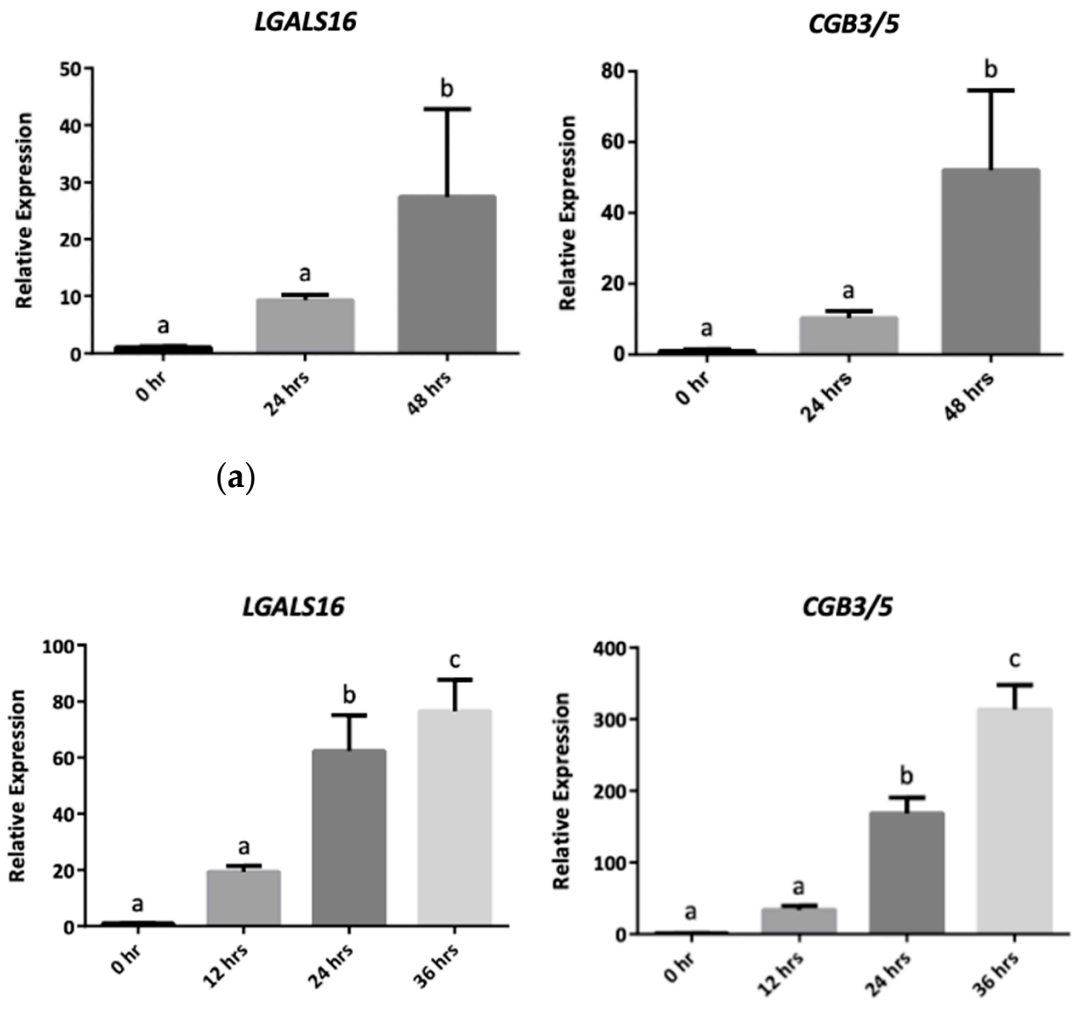

(b)

Figure 4. LGALS16 expression in human placental choriocarcinoma cell lines, BeWo and JEG-3. Cells were treated with 8-Br-cAMP $(250 \mu \mathrm{M})$ for different periods of time to induce syncytiotrophoblast differentiation. (a) BeWo cells $(n=4)$; (b) JEG-3 cells $(n=3)$. Agarose gels on the left confirm the expected size of PCR amplicons. Bar graphs show the fold changes in the expression of LGALS16 and CGB3/5 genes obtained by qPCR, which were quantified by the Livak method $\left(2^{-\triangle \Delta C T}\right)$ using $A C T B$ as a reference gene. Data are presented as means $\pm \mathrm{SD}$; means with the same letter are not significantly different from each other (Tukey's post hoc HSD test, $p>0.05$ ).

An important function of galectin-16 as well as placental galectin-13 and galectin-14 is the ability to induce apoptosis of CD3+ T cells, which was detected by flow cytometry of cells double-stained with annexin-V-FITC and propidium iodide [11]. Considering the high expression of galectin-16 in differentiated trophoblasts, the apoptotic mechanism might contribute to the immune tolerance at the maternal-fetal interface reducing the danger of maternal immune attacks on the fetus and enabling anthropoid primates to evolve long gestation periods while retaining highly invasive placentation. The details of this regulation are obscure since there are no studies addressing the secretion of galectin16 from trophoblasts. However, intracellular EGFP-tagged recombinant galectin-16 was readily localized in the nucleus and cytoplasm of transfected cells including, HeLa, 293T, HCT-116, SMMC-7721 and Jurkat cells [32]. In fact, the nuclear staining was much stronger than in the cytoplasm suggesting that the transport of galectin- 16 into the nucleus might play a role in regulating intranuclear processes. These authors showed that the binding partner of galectin-16 is c-Rel, a member of the NF- $\mathrm{kB}$ family of transcription factors (TFs), which is involved in the regulation of multiple processes such as apoptosis, inflammation, immune responses, tumorigenesis, cell growth and differentiation [32,36]. All NF- $\kappa B$ 
family members, including c-Rel, have a conserved N-terminal DNA-binding/dimerization domain, known as the Rel homology domain (RHD) [37]. Recombinant galectin-16 strongly binds to the RHD which might inhibit c-Rel and prevent activation of anti-apoptotic genes, such as Bcl-2 and Bcl-xL, promoting T-cell apoptosis during pregnancy [32]. An additional aspect of LGALS16 functions may contribute to the rescue of glucose restriction-induced cell death in a model of a whole genome gain-of-function CRISPR activation using human mitochondrial disease complex I mutant cells [38].

\subsection{Transcriptional and Post-Transcriptional Regulation of LGALS16 \\ 3.3.1. Transcription Factors}

Multiple TFs can be involved in the regulation of LGALS16 expression based on the presence of specific response elements in the promoter regions of the gene. Original analysis of retrotransposons within the $10 \mathrm{~kb} 5^{\prime}$ UTR by Than and co-authors demonstrated that the LGALS16 promoter has binding sites for GATA2, TEF5, and ESRRG, which are also involved in the regulation of important trophoblast-specific genes such as ERVWE1 (marker of cell fusion), CGA, and CGB3 (markers of chorionic gonadotropin production, a hormone released by differentiated trophoblasts to maintain pregnancy) [12]. The contribution of these TFs in regulating LGALS16 expression was claimed to vary, especially with decreased regulation from GATA2, due to the specific layout and properties of transposable elements (L1PA6 and L1PREC2) within the 5'UTR of this gene as compared to two other placental genes, LGALS13 and LGALS14. Additional shared TFs for the placental galectin gene cluster include TFAP2A and GCM1, which have binding sites within ALU transposable elements next to L1PREC2. Experimental evidence of this regulation was confirmed in a model of forskolin-induced differentiation of primary trophoblasts, which revealed timedependent upregulation of LGALS16 in parallel with the expression of TEAD3, ESRRG, GCM1, and ERVWE1 [12]. It is interesting to note that this study did not reveal the effect of 5-azacytidin on LGALS16 expression in BeWo trophoblast cells as compared to other upregulated placental galectins, which suggested a minor role of DNA methylation in the context of LGALS16 regulation.

To enrich this analysis, we used human choriocarcinoma cell line JEG-3 and Qiagen $\mathrm{RT}^{2}$ Profiler $^{\mathrm{TM}}$ PCR Array to test changes in the mRNA transcript levels of 84 TFs during trophoblastic differentiation induced by 8-Br-cAMP. Overall, 60 TFs were upregulated in this assay including three top genes encoding Jun B proto-oncogene (JUNB), SMAD family member 9 (SMAD9), and activating transcription factor 3 (ATF3) (Figure 5). Since all of these three genes are expressed in placenta and brain tissues [21,39-43], which are LGALS16-positive, this observation provides a new insight into possible transcriptional regulation of this gene. JUNB and ATF3 belong to a family of TFs with a basic leucine zipper DNA binding domain, with JUNB preferentially binding to the 12-O-tetradecanoylphorbol13-acetate response element sequence and ATF3 binding to the cAMP response element in promoters with the consensus sequence, TGACGTCA [44]. They are subunits of activating protein 1 (AP-1) TFs, which function as homodimers or heterodimers in association with other members of JUN, FOS, ATF, and MAF protein families [44]. JUNB was reported to be directly involved in processes of trophoblastic cell syncytialization $[45,46]$, while upregulation of ATF3 was associated with cellular stress responses [41,47,48], decidualization [47], and preeclampsia [49]. In comparison, SMAD9 is activated by bone morphogenic proteins (BMPs), a subfamily of the transforming growth factor- $\beta$ (TGF- $\beta$ ) family $[40,50]$. Although some BMPs such as BMP-4 can be regulated in a downstream manner from the cAMP pathway [51], the connection between SMAD9 and cAMP is still unclear. GATA2 was found to be slightly upregulated, which may suggest that the enrichment of L1PREC2 in the $5^{\prime}$ UTR still plays a role in regulating LGALS16 despite the insertion of L1PA6 [12]. Interestingly, CREB1, a major regulator downstream of the cAMP pathway was not upregulated in this RT-qPCR array analysis suggesting that post-translational modification and transcriptional activation might be essential for this TF. 


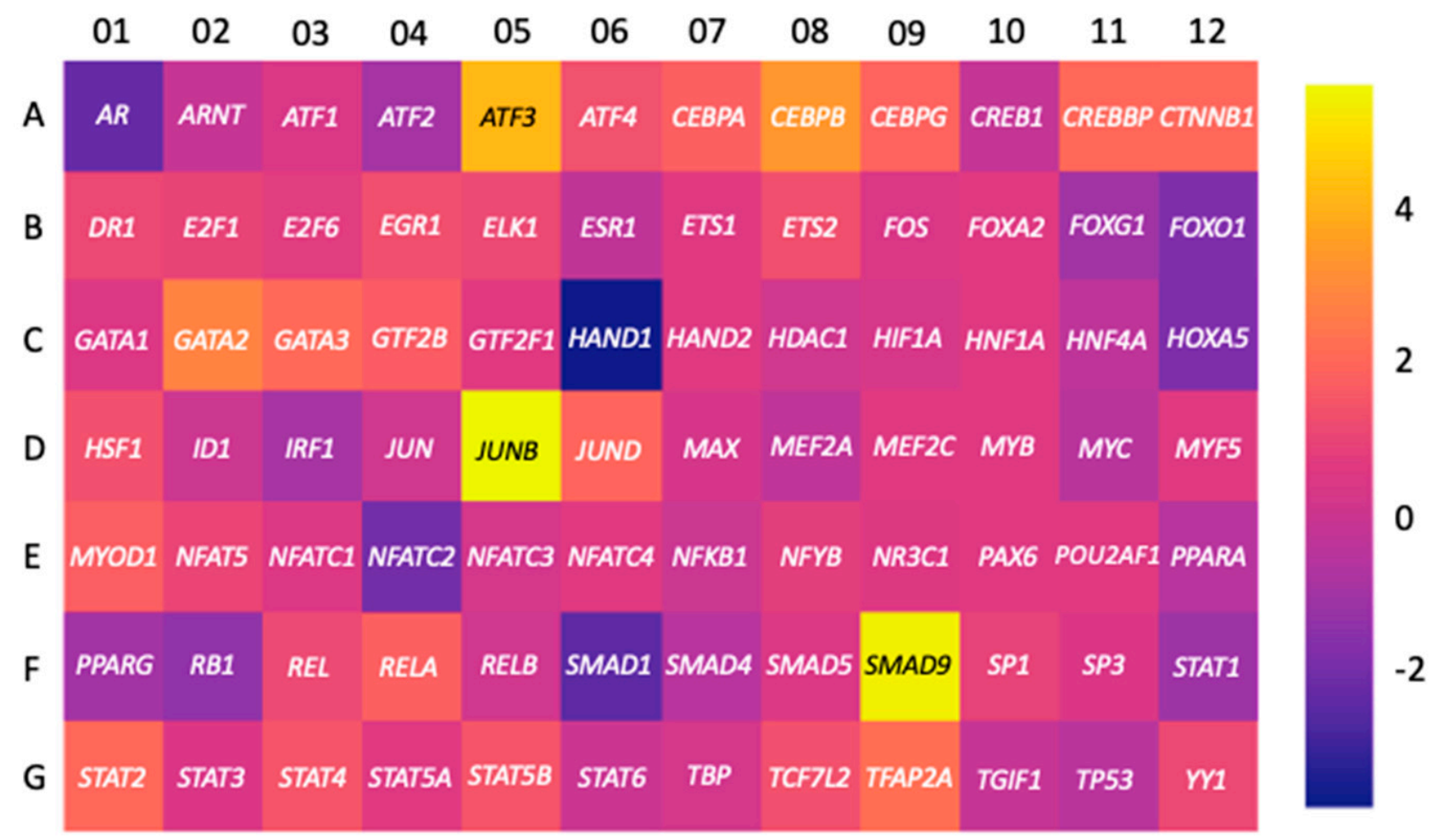

Figure 5. Changes in the expression of genes encoding TFs in JEG-3 cells. Cells were treated $8-\mathrm{Br}-\mathrm{cAMP}(250 \mu \mathrm{M})$ for $36 \mathrm{~h}$ to induce trophoblastic differentiation and Qiagen $\mathrm{RT}^{2}$ Profiler ${ }^{\mathrm{TM}} \mathrm{PCR}$ Array kit was used to assess fold changes in gene expression between differentiated and control cells presented as a heatmap.

We further analyzed the $2 \mathrm{~kb}$ region upstream from the transcription start site of LGALS16 by extracting the sequence from Ensembl (Release 104) and performing in silico analysis of TF-binding sites using PROMO virtual laboratory with a $0 \%$ dissimilarity index. Putative binding sites for seventeen TFs were identified, which may represent specific response elements, enhancers, or silencers (Figure 6). To reveal common patterns in the expression of the predicted TFs, we watched for their protein levels in two LGALS16-positive tissues, the cerebellum and placenta, using the expression scores (high, medium, low) available at HPA. Within this set of data, two TFs (CEBP $\beta$ and TFII-I) were characterized by high protein expression levels, seven TFs had variable levels (GR, NFAT1, p53, STAT4, TCF-4E, TFIID, and YY1), four TFs (ER $\alpha$, FOXP3, Pax5, and PR A) showed low expression, and no HPA data were available for GR $\alpha$, GR $\beta$, PR B, and XBP-1 in these tissues (Figure 7). Thus, the role of the predicted TFs in tissue-specific transcriptional regulation of LGALS16 can be different and remains to be studied.

\begin{tabular}{|l|l|l|l|l|l|}
\hline CEBP $\beta$ & GR & NF-AT1 & PR A & TCF-4E & XBP-1 \\
ER $\alpha$ & GR $\alpha$ & p53 & PR B & TFIID & YY1 \\
\hline FOXP3 & GR $\beta$ & Pax-5 & STAT4 & TFII-I & \\
\hline
\end{tabular}

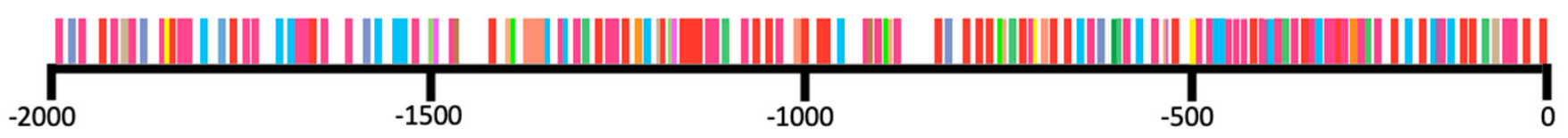

Figure 6. In silico screening of putative transcription factor binding sites for the LGALS16 gene. There are multiple binding sites for 17 transcription factors within the $2 \mathrm{~kb}$ promoter region upstream the transcription start site of LGALS16 gene as detected by PROMO. 


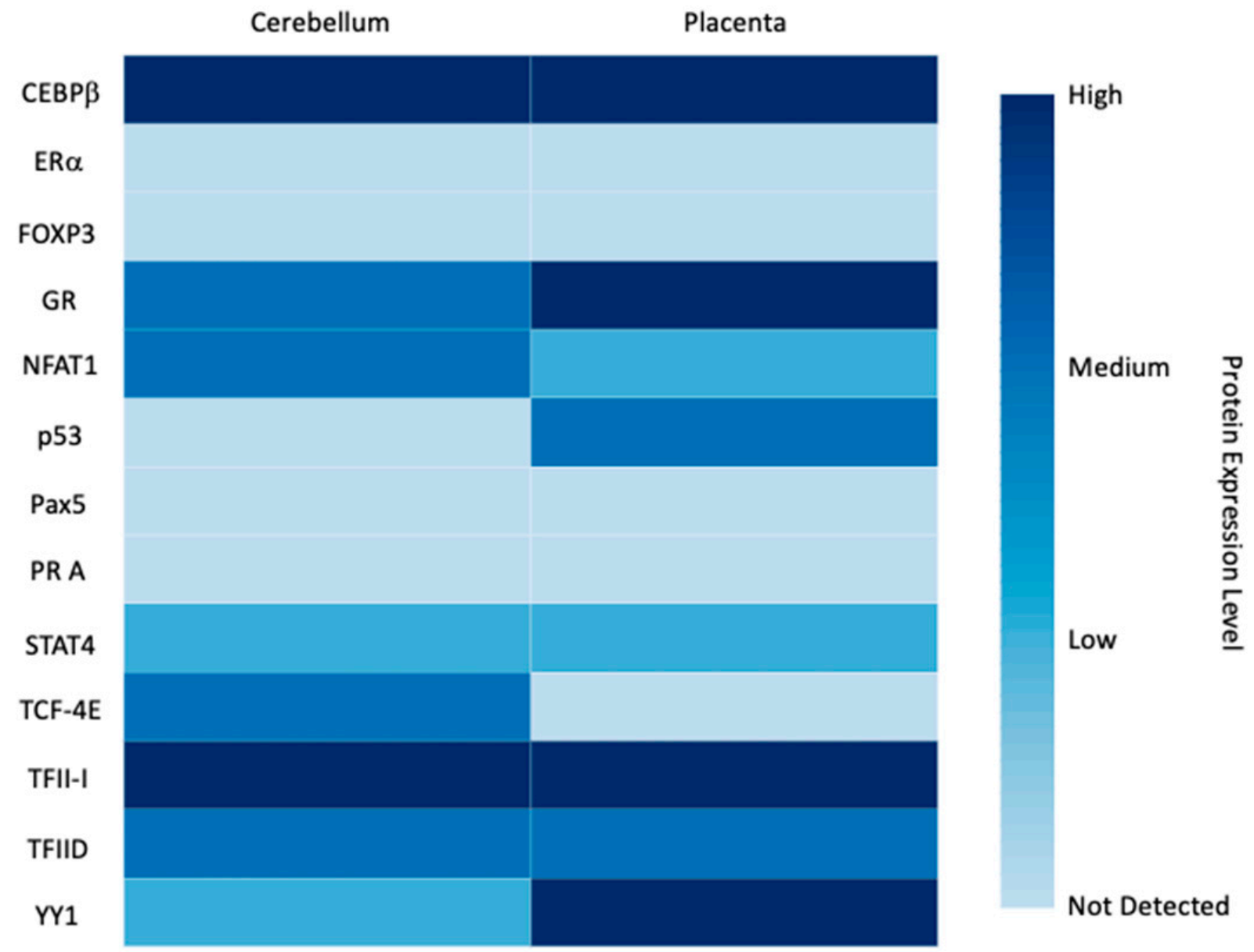

Figure 7. Protein expression patterns of predicted transcription factors for LGALS16 regulation in the cerebellum and placenta.

\subsection{2. miRNAs}

Post-transcriptional control of mRNA availability for protein synthesis depends on miRNAs which can hybridize to complementary sequences in protein-coding mRNAs at the $3^{\prime}$ untranslated region and either block protein translation or induce mRNA degradation [52]. Multiple miRNAs were predicted to target the LGALS16 transcript by bioinformatics tools, such as Diana Tools [17], miRabel [18], miRDB [19], and TargetScan [20], which use different algorithms and methods. A robust application of these tools using default options shows that five miRNAs (hsa-miR-3155a, hsa-miR-3155b, hsa-miR-4689, hsa-miR-4778-5p, hsa-miR-6783-5p) are predicted by all four of these online platforms (Figure 8). These miRNAs among others can be considered as perspective candidates for regulating the stability and / or translational potential of the LGALS16 transcripts, especially in relevant tissues such as placenta and brain. Indeed, a significant decrease in hsa-miR-4778-5p expression during gestation in exosomes from maternal blood was associated with preterm birth pregnancies [53]. Expression of hsa-miR-3155a was significantly upregulated in the anterior cingulate cortex of deceased patients with major depressive disorder [54]. In comparison, the expression of hsa-miR-4689 was downregulated in exosomes isolated from the plasma of patients with mesial temporal lobe epilepsy with hippocampal sclerosis compared to controls [55]. Differential expression of exosomal hsa-miR-4689 and hsa-miR-6783-5p was reported in patients with intracranial aneurysms [56]. Human miRNA tissue atlas confirms expression of hsa-miR-3155a, hsa-miR-3155b, hsa-miR-4689, and hsa-miR-4778-5p in brain among other tissues at variable levels [57]. Unraveling possible mechanisms of miRNA-mediated regulation of galectin-16 in these tissues awaits future research. 


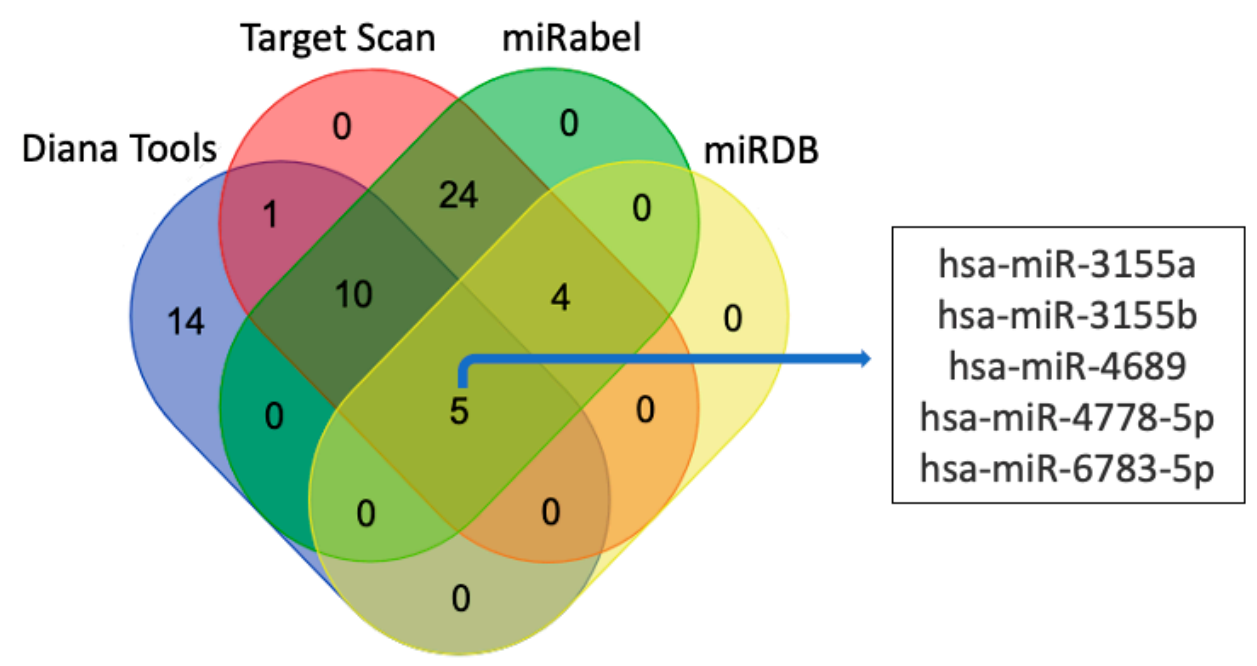

Figure 8. Putative miRNAs targeting LGALS16 mRNA transcript. Five miRNAs are unanimously predicted by four different online platforms such as Diana Tools, miRabel, miRDB, and TargetScan.

\subsection{LGALS16 and Human Diseases}

Dysregulation of the placenta-specific gene cluster containing LGALS16 is associated with a pregnancy complication known as preeclampsia, which can be highly fatal for both the mother and fetus. As such, LGALS16 together with LGALS13 and LGALS14 were confirmed to satisfy the criteria of placenta enriched genes in a comprehensive study of RNA-Seq datasets from 302 placental biopsies [58]. However, although increasing expression of LGALS13, LGALS14, and LGALS16 was observed during forskolin-induced syncytialization and differentiation of primary trophoblasts and BeWo cells in culture, only LGALS13 and LGALS14 were downregulated in preeclampsia with no significant changes of LGALS16 [12]. Remarkably, LGALS16 does not show sex-biased expression depending on the chromosomal sex of the fetus while LGALS13 and LGALS14 are notably elevated in fetal male placentas based on the chorionic villus transcriptome [59]. These aspects of galectin network regulation remain unclear in the context of placental disorders and development.

Alterations in the expression or mutations of LGALS16 have been also reported for several other diseases and based mostly on microarray and RNA-Seq analysis, although the application of this gene as a biomarker is still unknown. Gene expression profiling with RNA sequencing data revealed that LGALS16 was detected as an upregulated gene in fusiform gyrus tissue sections of 219 autopsy-confirmed Alzheimer's cases versus 70 neurologically normal age-matched controls [60]. LGALS16 was also recognized as a brain tissue-specific gene within genome-wide associations with several neuroimaging psychiatric traits [61]. Further, LGALS16 was expressed two-fold higher in chronic myeloid leukemia granulocytes compared to controls [62]. Copy number variations were identified in chromosome 19 for multiple genes including LGALS16 in association with clinical features, such as histological type, ethnicity, disease stage, and familial history, of breast cancer using tumor samples from a Brazilian cohort [63]. In addition, LGALS16 was determined to be a moderate impact variant associated with autism spectrum disorder, consisting of a missense single nucleotide variant (SNV), which was reported as detrimental by bioinformatic tools SIFT and PolyPhen-2 [64]. LGALS16 also had greater SNVs within the $3^{\prime}$ flank region with one or more mutations in patients with diffuse large B-cell lymphoma [65]. Moreover, a LGALS16 SNP was revealed to be associated with insulin secretion in a cohort of African Americans [66]. This study also showed that interactions between this LGALS16 SNP and others, such as an intergenic SNP upstream of the LYPLAL1 gene, have also been associated with type 2 diabetes risk. The LGALS16 transcript was one of the top 50 down-regulated mRNA present in the exosomes isolated from the cerebrospinal fluid in patients with meningeal carcinomatosis in comparison with healthy controls [67]. 


\section{Conclusions}

Although the galectin-16 gene was described more than 10 years ago [11], the regulation, functions, and clinical aspects of this tissue-specific molecule are largely unexplored. Primary association of LGALS16 with placental tissue has been challenged by its detection in brain tissues and several cancer cell lines as followed from available microarray and RNA-seq databases. There are bioinformatics indications that the expression of LGALS16 changes in association with Alzheimer's disease, chronic myeloid leukemia, breast cancer, B-cell lymphoma, and type 2 diabetes. Although LGALS16 was not significantly impacted at the gene level in preeclampsia, there remain questions regarding regulation at the protein level, which cannot be properly addressed at this time due to the absence of commercially available specific galectin- 16 antibodies. The results obtained with recombinant galectin16 are promising, but there is still a gap in our understanding of why the expression of endogenous galectin- 16 protein has not been reported. Nevertheless, among the possible functions of galectin-16 in these and other tissues, its contribution to the regulation of cellular differentiation and programmed cell death (apoptosis) warrants special attention. Lastly, the use of proper cell culture models and the examination of multiple factors (transcription regulators and miRNA) is evidently the first line of study to position galectin-16 within a complex galectin network in cells. The generation of galectin-16-specific antibody and LGALS16 knockout cell lines using CRISPR/Cas9 technology might be required steps to unravel the role and significance of this molecule in the context of cell biology.

Author Contributions: Conceptualization, A.V.T.; methodology, A.V.T. and J.D.K.; formal analysis, A.V.T. and J.D.K.; investigation, J.D.K.; writing-original draft preparation, J.D.K.; writing-review and editing, A.V.T. and J.D.K.; supervision, A.V.T.; funding acquisition, A.V.T. All authors have read and agreed to the published version of the manuscript.

Funding: This research was supported in part by a Discovery Grant from The Natural Sciences and Engineering Research Council of Canada (RGPIN-2019-06628) to A.V.T., J.D.K. is a recipient of the Canada Graduate Scholarship-Master's Program from The Natural Sciences and Engineering Research Council of Canada.

Data Availability Statement: The data presented in this study are available on request from the corresponding author.

Acknowledgments: We would like to thank Ahmad Butt and Haya Tawfik for their assistance in the collecting records for Table 1.

Conflicts of Interest: The authors declare no conflict of interest.

\section{References}

1. Timoshenko, A.V. Towards molecular mechanisms regulating the expression of galectins in cancer cells. Cell. Mol. Life Sci. 2015, 72, 4327-4340. [CrossRef] [PubMed]

2. Allo, V.C.M.; Toscano, M.A.; Pinto, N.; Rabinovich, G.A. Galectins: Key players at the frontiers of innate and adaptive immunity. Trends Glycosci. Glycotechnol. 2018, 30, SE97-SE107. [CrossRef]

3. Johannes, L.; Jacob, R.; Leffler, H. Galectins at a glance. J. Cell Sci. 2018, 131, jcs208884. [CrossRef] [PubMed]

4. Tazhitdinova, R.; Timoshenko, A.V. The emerging role of galectins and O-GlcNAc homeostasis in processes of cellular differentiation. Cells 2020, 9, 8. [CrossRef] [PubMed]

5. Vladoiu, M.C.; Labrie, M.; St-Pierre, Y. Intracellular galectins in cancer cells: Potential new targets for therapy (Review). Int. J. Oncol. 2014, 44, 1001-1014. [CrossRef]

6. Patterson, R.J.; Haudek, K.C.; Voss, P.G.; Wang, J.L. Examination of the role of galectins in pre-mRNA splicing. Methods Mol. Biol. 2015, 1207, 431-449.

7. Popa, S.J.; Stewart, S.E.; Moreau, K. Unconventional secretion of annexins and galectins. Semin. Cell Dev. Biol. 2018, 83, 42-50. [CrossRef] [PubMed]

8. He, J.; Baum, L.G. Galectin interactions with extracellular matrix and effects on cellular function. Methods Enzymol. 2006, $417,247-256$.

9. Nabi, I.R.; Shankar, J.; Dennis, J.W. The galectin lattice at a glance. J. Cell Sci. 2015, 128, 2213-2219. [CrossRef]

10. Than, N.G.; Romero, R.; Kim, C.J.; McGowen, M.R.; Papp, Z.; Wildman, D.E. Galectins: Guardians of eutherian pregnancy at the maternal-fetal interface. Trends Endocrinol. Metab. 2012, 23, 23-31. [CrossRef] [PubMed] 
11. Than, N.G.; Romero, R.; Goodman, M.; Weckle, A.; Xing, J.; Dong, Z.; Xu, Y.; Tarquini, F.; Szilagyi, A.; Gal, P.; et al. A primate subfamily of galectins expressed at the maternal-fetal interface that promote immune cell death. Proc. Natl. Acad. Sci. USA 2009, 106, 9731-9736. [CrossRef]

12. Than, N.G.; Romero, R.; Xu, Y.; Erez, O.; Xu, Z.; Bhatti, G.; Leavitt, R.; Chung, T.H.; El-Azzamy, H.; LaJeunesse, C.; et al. Evolutionary origins of the placental expression of chromosome 19 cluster galectins and their complex dysregulation in preeclampsia. Placenta 2014, 35, 855-865. [CrossRef]

13. Pollheimer, J.; Vondra, S.; Baltayeva, J.; Beristain, A.G.; Knöfler, M. Regulation of placental extravillous trophoblasts by the maternal uterine environment. Front. Immunol. 2018, 9, 2597. [CrossRef]

14. Blois, S.M.; Dveksler, G.; Vasta, G.R.; Freitag, N.; Blanchard, V.; Barrientos, G. Pregnancy galectinology: Insights into a complex network of glycan binding proteins. Front. Immunol. 2019, 10, 1166. [CrossRef] [PubMed]

15. Messeguer, X.; Escudero, R.; Farré, D.; Núñez, O.; Martínez, J.; Albà, M.M. PROMO: Detection of known transcription regulatory elements using species-tailored searches. Bioinformatics 2002, 18, 333-334. [CrossRef] [PubMed]

16. Farré, D.; Roset, R.; Huerta, M.; Adsuara, J.E.; Roselló, L.; Albà, M.M.; Messeguer, X. Identification of patterns in biological sequences at the ALGGEN server: PROMO and MALGEN. Nucleic Acids Res. 2003, 31, 3651-3653. [CrossRef] [PubMed]

17. Paraskevopoulou, M.D.; Georgakilas, G.; Kostoulas, N.; Vlachos, I.S.; Vergoulis, T.; Reczko, M.; Filippidis, C.; Dalamagas, T.; Hatzigeorgiou, A.G. DIANA-microT web server v5.0: Service integration into miRNA functional analysis workflows. Nucleic Acids Res. 2013, 41, W169-W173. [CrossRef] [PubMed]

18. Quillet, A.; Saad, C.; Ferry, G.; Anouar, Y.; Vergne, N.; Lecroq, T.; Dubessy, C. Improving bioinformatics prediction of microRNA targets by ranks aggregation. Front. Genet. 2020, 10, 1330. [CrossRef] [PubMed]

19. Chen, Y.; Wang, X. miRDB: An online database for prediction of functional microRNA targets. Nucleic Acids Res. 2020, 48, D127-D131. [CrossRef] [PubMed]

20. Agarwal, V.; Bell, G.W.; Nam, J.W.; Bartel, D.P. Predicting effective microRNA target sites in mammalian mRNAs. eLife 2015, 4, e05005. [CrossRef]

21. Uhlén, M.; Fagerberg, L.; Hallström, B.M.; Lindskog, C.; Oksvold, P.; Mardinoglu, A.; Sivertsson, A.; Kampf, C.; Sjöstedt, E.; Asplund, A. Tissue-based map of the human proteome. Science 2015, 347, 1260419. [CrossRef]

22. Clark, K.; Karsch-Mizrachi, I.; Lipman, D.J.; Ostell, J.; Sayers, E.W. GenBank. Nucleic Acids Res. 2016, 44, D67-D72. [CrossRef] [PubMed]

23. Berman, H.M.; Westbrook, J.; Feng, Z.; Gilliland, G.; Bhat, T.N.; Weissig, H.; Shindyalov, I.N.; Bourne, P.E. The protein data bank. Nucleic Acids Res. 2000, 28, 235-242. [CrossRef] [PubMed]

24. Ye, J.; Coulouris, G.; Zaretskaya, I.; Cutcutache, I.; Rozen, S.; Madden, T.L. Primer-BLAST: A tool to design target-specific primers for polymerase chain reaction. BMC Bioinform. 2012, 13, 134. [CrossRef] [PubMed]

25. Timoshenko, A.V. Chitin hydrolysate stimulates VEGF-C synthesis by MDA-MB-231 breast cancer cells. Cell Biol. Int. 2011, 35, 281-286. [CrossRef]

26. Renaud, S.J.; Chakraborty, D.; Mason, C.W.; Rumi, M.A.; Vivian, J.L.; Soares, M.J. OVO-like 1 regulates progenitor cell fate in human trophoblast development. Proc. Natl. Acad. Sci. USA 2015, 112, E6175-E6184. [CrossRef] [PubMed]

27. Timoshenko, A.V.; Lanteigne, J.; Kozak, K. Extracellular stress stimuli alter galectin expression profiles and adhesion characteristics of HL-60 cells. Mol. Cell Biochem. 2016, 413, 137-143. [CrossRef]

28. Sherazi, A.A.; Jariwala, K.A.; Cybulski, A.N.; Lewis, J.W.; Karagiannis, J.; Cumming, R.C.; Timoshenko, A.V. Effects of global O-GlcNAcylation on galectin gene-expression profiles in human cancer cell lines. Anticancer Res. 2018, 38, 6691-6697. [CrossRef] [PubMed]

29. Ely, A.Z.; Moon, J.M.; Sliwoski, G.R.; Sangha, A.K.; Shen, X.-X.; Labella, A.L.; Meiler, J.; Capra, J.A.; Rokas, A. The impact of natural selection on the evolution and function of placentally expressed galectins. Genome Biol. Evol. 2019, 11, 2574-2592. [CrossRef]

30. Singer, M.F. SINEs and LINEs: Highly repeated short and long interspersed sequences in mammalian genomes. Cell 1982, 28, 433-434. [CrossRef]

31. Weckselblatt, B.; Rudd, M.K. Human structural variation: Mechanisms of chromosome rearrangements. Trends Genet. 2015, 31, 587-599. [CrossRef] [PubMed]

32. Si, Y.; Yao, Y.; Ayala, G.J.; Li, X.; Han, Q.; Zhang, W.; Xu, X.; Tai, G.; Mayo, K.H.; Zhou, Y.; et al. Human galectin-16 has a pseudo ligand binding site and plays a role in regulating c-Rel mediated lymphocyte activity. Biochim. Biophys. Acta Gen. Subj. 2021, 1865, 129755. [CrossRef] [PubMed]

33. Barrett, T.; Wilhite, S.E.; Ledoux, P.; Evangelista, C.; Kim, I.F.; Tomashevsky, M.; Marshall, K.A.; Phillippy, K.H.; Sherman, P.M.; Holko, M.; et al. NCBI GEO: Archive for functional genomics data sets-Update. Nucleic Acids Res. 2013, 41, D991-D995. [CrossRef]

34. Rosenfeld, C.S. The placenta-brain-axis. J. Neurosci. Res. 2021, 99, 271-283. [CrossRef]

35. Inamochi, Y.; Mochizuki, K.; Goda, T. Histone code of genes induced by co-treatment with a glucocorticoid hormone agonist and a p44/42 MAPK inhibitor in human small intestinal Caco-2 cells. Biochim. Biophys. Acta 2014, 1840, 693-700. [CrossRef] [PubMed]

36. Park, M.H.; Hong, J.T. Roles of NF-kB in cancer and inflammatory diseases and their therapeutic approaches. Cells 2016, 5, 15. [CrossRef]

37. Hayden, M.S.; Ghosh, S. NF-kB in immunobiology. Cell Res. 2011, 21, 223-244. [CrossRef] 
38. Balsa, E.; Perry, E.A.; Bennett, C.F.; Jedrychowski, M.; Gygi, S.P.; Doench, J.G.; Puigserver, P. Defective NADPH production in mitochondrial disease complex I causes inflammation and cell death. Nat. Commun. 2020, 11, 2714. [CrossRef]

39. Nuzzo, A.M.; Giuffrida, D.; Zenerino, C.; Piazzese, A.; Olearo, E.; Todros, T.; Rolfo, A. JunB/Cyclin-D1 imbalance in placental mesenchymal stromal cells derived from preeclamptic pregnancies with fetal-placental compromise. Placenta 2014, 35, 483-490. [CrossRef]

40. Han, Y.M.; Romero, R.; Kim, J.S.; Tarca, A.L.; Kim, S.K.; Draghici, S.; Kusanovic, J.P.; Gotsch, F.; Mittal, P.; Hassan, S.S.; et al. Region-specific gene expression profiling: Novel evidence for biological heterogeneity of the human amnion. Biol. Reprod. 2008, 79, 954-961. [CrossRef]

41. Knyazev, E.N.; Zakharova, G.S.; Astakhova, L.A.; Tsypina, I.M.; Tonevitsky, A.G.; Sukhikh, G.T. Metabolic reprogramming of trophoblast cells in response to hypoxia. Bull. Exp. Biol. Med. 2019, 166, 321-325. [CrossRef] [PubMed]

42. Walcott, B.P.; Winkler, E.A.; Zhou, S.; Birk, H.; Guo, D.; Koch, M.J.; Stapleton, C.J.; Spiegelman, D.; Dionne-Laporte, A.; Dion, P.A.; et al. Identification of a rare BMP pathway mutation in a non-syndromic human brain arteriovenous malformation via exome sequencing. Hum. Genome Var. 2018, 5, 18001. [CrossRef] [PubMed]

43. Ma, S.; Pang, C.; Song, L.; Guo, F.; Sun, H. Activating transcription factor 3 is overexpressed in human glioma and its knockdown in glioblastoma cells causes growth inhibition both in vitro and in vivo. Int. J. Mol. Med. 2015, 35, 1561-1573. [CrossRef]

44. Garces de Los Favos Alonso, I.; Liang, H.C.; Turner, S.D.; Lagger, S.; Merkel, O.; Kenner, L. The role of activator protein-1 (AP-1) family members in CD30-positive lymphomas. Cancers 2018, 10, 93. [CrossRef]

45. Shankar, K.; Kang, P.; Zhong, Y.; Borengasser, S.J.; Wingfield, C.; Saben, J.; Gomez-Acevedo, H.; Thakali, K.M. Transcriptomic and epigenomic landscapes during cell fusion in BeWo trophoblast cells. Placenta 2015, 36, 1342-1351. [CrossRef]

46. Cheng, Y.-H.; Richardson, B.D.; Hubert, M.A.; Handwerger, S. Isolation and characterization of the human syncytin gene promoter. Biol. Reprod. 2004, 70, 694-701. [CrossRef] [PubMed]

47. Wang, Z.; Liu, Y.; Liu, J.; Kong, N.; Jiang, Y.; Jiang, R.; Zhen, X.; Zhou, J.; Li, C.; Sun, H.; et al. ATF3 deficiency impairs the proliferative-secretory phase transition and decidualization in RIF patients. Cell Death Dis. 2021, 12, 387. [CrossRef]

48. Jadhav, K.; Zhang, Y. Activating transcription factor 3 in immune response and metabolic regulation. Liver Res. 2017, 1, 96-102. [CrossRef]

49. Moslehi, R.; Mills, J.L.; Signore, C.; Kumar, A.; Ambroggio, X.; Dzutsev, A. Integrative transcriptome analysis reveals dysregulation of canonical cancer molecular pathways in placenta leading to preeclampsia. Sci. Rep. 2013, 3, 2407. [CrossRef]

50. Tsukamoto, S.; Mizuta, T.; Fujimoto, M.; Ohte, S.; Osawa, K.; Miyamoto, A.; Yoneyama, K.; Murata, E.; Machiya, A.; Jimi, E.; et al. Smad9 is a new type of transcriptional regulator in bone morphogenetic protein signaling. Sci. Rep. 2014, 4, 7596. [CrossRef]

51. Heo, K.S.; Fujiwara, K.; Abe, J. Disturbed-flow-mediated vascular reactive oxygen species induce endothelial dysfunction. Circ. J. 2011, 75, 2722-2730. [CrossRef] [PubMed]

52. Fabian, M.R.; Sonenberg, N.; Filipowicz, W. Regulation of mRNA translation and stability by microRNAs. Annu. Rev. Biochem. 2010, 79, 351-379. [CrossRef] [PubMed]

53. Menon, R.; Debnath, C.; Lai, A.; Guanzon, D.; Bhatnagar, S.; Kshetrapal, P.K.; Sheller-Miller, S.; Salomon, C.; Garbhini Study Team. Circulating exosomal miRNA profile during term and preterm birth pregnancies: A longitudinal study. Endocrinology 2019, 160, 249-275. [CrossRef]

54. Yoshino, Y.; Roy, B.; Dwivedi, Y. Altered miRNA landscape of the anterior cingulate cortex is associated with potential loss of key neuronal functions in depressed brain. Eur. Neuropsychopharmacol. 2020, 40, 70-84. [CrossRef]

55. Yan, S.; Zhang, H.; Xie, W.; Meng, F.; Zhang, K.; Jiang, Y.; Zhang, X.; Zhang, J. Altered microRNA profiles in plasma exosomes from mesial temporal lobe epilepsy with hippocampal sclerosis. Oncotarget 2017, 8, 4136-4146. [CrossRef] [PubMed]

56. Liao, B.; Zhou, M.X.; Zhou, F.K.; Luo, X.M.; Zhong, S.X.; Zhou, Y.F.; Qin, Y.S.; Li, P.P.; Qin, C. Exosome-derived miRNAs as biomarkers of the development and progression of intracranial aneurysms. J. Atheroscler. Thromb. 2020, 27, 545-610. [CrossRef]

57. Ludwig, N.; Leidinger, P.; Becker, K.; Backes, C.; Fehlmann, T.; Pallasch, C.; Rheinheimer, S.; Meder, B.; Stähler, C.; Meese, E.; et al. Distribution of miRNA expression across human tissues. Nucleic Acids Res. 2016, 44, 3865-3877. [CrossRef]

58. Gong, S.; Gaccioli, F.; Dopierala, J.; Sovio, U.; Cook, E.; Volders, P.J.; Martens, L.; Kirk, P.D.W.; Richardson, S.; Smith, G.C.S.; et al. The RNA landscape of the human placenta in health and disease. Nat. Commun. 2021, 12, 2639. [CrossRef] [PubMed]

59. Braun, A.E.; Muench, K.L.; Robinson, B.G.; Wang, A.; Palmer, T.D.; Winn, V.D. Examining Sex Differences in the Human Placental Transcriptome During the First Fetal Androgen Peak. Reprod Sci. 2021, 28, 801-818. [CrossRef]

60. Vastrad, B.; Vastrad, C. Bioinformatics analyses of significant genes, related pathways and candidate prognostic biomarkers in Alzheimer's disease. BioRxiv 2021. [CrossRef]

61. Zhao, B.; Shan, Y.; Yang, Y.; Zhaolong, Y.; Li, T.; Wang, X.; Luo, T.; Zhu, Z.; Sullivan, P.; Zhao, H.; et al. Transcriptome-wide association analysis of brain structures yields insights into pleiotropy with complex neuropsychiatric traits. Nat. Commun. 2021, 12, 2878. [CrossRef] [PubMed]

62. Čokić, V.P.; Mojsilović, S.; Jauković, A.; Kraguljac-Kurtović, N.; Mojsilović, S.; Šefer, D.; Mitrović Ajtić, O.; Milošević, V.; Bogdanović, A.; Đikić, D.; et al. Gene expression profile of circulating CD34(+) cells and granulocytes in chronic myeloid leukemia. Blood Cells Mol. Dis. 2015, 55, 373-381. [CrossRef] [PubMed]

63. Rodrigues-Peres, R.M.; de Carvalho, B.S.; Anurag, M.; Lei, J.T.; Conz, L.; Gonçalves, R.; Cardoso Filho, C.; Ramalho, S.; de Paiva, G.R.; Derchain, S.; et al. Copy number alterations associated with clinical features in an underrepresented population with breast cancer. Mol. Genet. Genomic. Med. 2019, 7, e00750. [CrossRef] [PubMed] 
64. Santos, J.X.; Rasga, C.; Marques, A.R.; Martiniano, H.F.M.C.; Asif, M.; Vilela, J.; Oliveira, G.; Vicente, A.M. A role for geneenvironment interactions in Autism Spectrum Disorder is suggested by variants in genes regulating exposure to environmental factors. BioRxiv 2019. [CrossRef]

65. Arthur, S.E.; Jiang, A.; Grande, B.M.; Alcaide, M.; Cojocaru, R.; Rushton, C.K.; Mottok, A.; Hilton, L.K.; Kumar Lat, P.; Zhao, E.Y. Genome-wide discovery of somatic regulatory variants in diffuse large B-cell lymphoma. Nat. Commun. 2018, 9, 4001. [CrossRef] [PubMed]

66. Keaton, J.M.; Hellwege, J.N.; Ng, M.C.; Palmer, N.D.; Pankow, J.S.; Fornage, M.; Wilson, J.G.; Correa, A.; Rasmussen-Torvik, L.J.; Rotter, J.I.; et al. Genome-wide interaction with insulin secretion loci reveals novel loci for type 2 diabetes in African Americans. PLoS ONE 2016, 11, e0159977. [CrossRef]

67. Cheng, P.; Feng, F.; Yang, H.; Jin, S.; Lai, C.; Wang, Y.; Bi, J. Detection and significance of exosomal mRNA expression profiles in the cerebrospinal fluid of patients with meningeal carcinomatosis. J. Mol. Neurosci. 2021, 71, 790-803. [CrossRef] 